Rev Inv Vet Perú 2014; 25(2): 329-332

doi: http://doi.org/10.15381/rivep.v25i2.8506

\title{
Comunicación
}

\section{ENDOCARDITIS BACTERIANA: REPORTE DE CASO}

\author{
Bacterial Endocarditis: Case Report
}

Roberto Dávila F. ${ }^{1,2}$, Miguel Marroquín A. ${ }^{1}$

\section{Resumen}

La endocarditis bacteriana es una inflamación del endocardio donde hay colonización bacteriana que genera vegetaciones en alguna válvula del corazón, las cuales alteran la función cardiaca generando regurgitaciones y alteraciones hemodinámicas. Además, puede producir cuadros propios de la infección como tromboembolismo séptico y alteraciones inflamatorias como complejos inmunes. En el presente estudio se describe el caso de un canino hembra de 2.5 años, que presentó fiebre, decaimiento, anorexia y un soplo marcado (IV/VI) en el lado izquierdo del tórax. Los exámenes de laboratorio evidenciaron leucocitosis con desviación a la izquierda e insuficiencia renal aguda. Además, la ecocardiografía mostró un crecimiento a nivel de la válvula aórtica que alteraba el flujo sanguíneo produciendo un jet regurgitante diastólico. Se concluye que la lesión era compatible con una endocarditis bacteriana.

Palabras clave: canino, ecocardiografía, endocarditis bacteriana

\section{Abstract}

Bacterial endocarditis is an inflammation of the endocardium, where a bacterial colonization produces vegetation in the cardiac valve, which can alter its normal function causing regurgitations and hemodynamic alterations. Also, this infection can cause septic thromboembolism or inflammatory alterations like immune complexes. The present study describes the case of a female canine of 2.5 years of age that presented fever, depression, anorexia and a severe murmur (IV/VI) on the left side of the thorax. Laboratory exams revealed leukocytosis with left shift and renal failure. Besides, the echocardiography

${ }^{1}$ Clínica de Animales Menores, Facultad de Medicina Veterinaria, Universidad Nacional Mayor de San Marcos, Lima

${ }^{2}$ E-mail: rodaf45@yahoo.com

Recibido: 25 de noviembre de 2013

Aceptado para publicación: 15 de enero de 2014 
showed vegetation at the aortic valve that altered the hemodynamics producing a diastolic regurgitation jet. It was concluded that the lesion was compatible with bacterial endocarditis.

Key words: canine, echocardiography, bacterial endocarditis

\section{INTRODUCCIÓN}

La endocarditis bacteriana es una enfermedad causada por una colonización bacteriana que ocasiona alteraciones de las válvulas cardiacas (Martin y Corcorán, 1997). Ocurre una alteración microscópica del endocardio valvular y exposición del colágeno subendocárdico que permite la adhesión bacteriana ante una bacteriemia transitoria $o$ permanente, siendo la válvula aórtica, y en menor frecuencia, la mitral las más afectadas (Martin y Corcorán, 1997; Kittleson y Kienle, 1998). La prevalencia de la enfermedad es muy baja y normalmente ocurre en perros jóvenes con más de $15 \mathrm{~kg}$ de peso, donde la frecuencia es de 2 a 1 en relación a machos y hembras (Kittleson y Kienle, 1998; Belerian et al., 2001).

El cuadro clínico usualmente incluye fiebre, anorexia, decaimiento, síntomas de insuficiencia cardiaca congestiva izquierda como nuevo soplo cardiaco regurgitante, alteraciones causadas por tromboembolismo (infarto embólico), arritmias, dolor abdominal, cojera e insuficiencia renal. Además, la bacteremia persistente puede estimular el sistema inmune humoral y celular formando complejos inmunes que producen glomerulonefritis y artritis (Tilley et al., 2008). Los exámenes de laboratorio muestran leucocitosis con desviación a la izquierda, anemia normocítica normocrómica, monocitosis y, algunas veces, azotemia e hipoalbuminemia por glomerulonefritis (Belerian et al., 2001; Tilley et al., 2008).

El diagnóstico se basa en criterios clínicos (principales, secundarios, complementa- rios) y patológicos que incluyen la evidencia de vegetaciones valvulares y regurgitaciones a la ecocardiografía (Kittleson y Kienle, 1998). El tratamiento se basa en el manejo de la insuficiencia cardiaca congestiva y antibióticos bactericidas de amplio espectro como ampicilina, oxacilina, gentamicina, amikacina y fluroquinolonas (Fox et al., 1999; Lynne, 2003). El pronóstico de la enfermedad es malo, pues los pacientes normalmente fallecen por la insuficiencia cardiaca, otros por complicaciones embólicas e insuficiencia renal, o debido a complicaciones de carácter infeccioso (Kittleson y Kienle, 1998; Belerian et al., 2001).

\section{Caso Clínico}

Paciente canino, hembra, cruzada, de 2.5 años de edad y peso vivo de $17.2 \mathrm{~kg}$, proveniente de la ciudad de Lima fue admitida en la Clínica de Animales Menores de la Facultad de Medicina Veterinaria, Universidad Nacional Mayor de San Marcos, Lima. La paciente presentó decaimiento, anorexia y había tenido episodios febriles previos, por lo que ya había sido atendido en otra clínica veterinaria. En el examen clínico se evidenciaron mucosas rosadas, frecuencia cardiaca elevada (>180 lpm), disnea, condición corporal de $2 / 5$ y un tiempo de llenado capilar de 2 segundos. No había indicios de deshidratación. Además, se auscultó un soplo marcado (IV/VI) en la base cardiaca izquierda.

Se realizaron análisis de sangre y uroanálisis, encontrando anemia macrocítica hipercrómica ( $31 \%$ de hematocrito), sin leucocitosis $\left(7700 \times 10^{3} / \mu \mathrm{l}\right)$, uremia $(132 \mathrm{mg} /$ dl) y creatinemia $(3.6 \mathrm{mg} / \mathrm{dl})$ con proteinuria moderada. En el sedimento urinario se ob- 


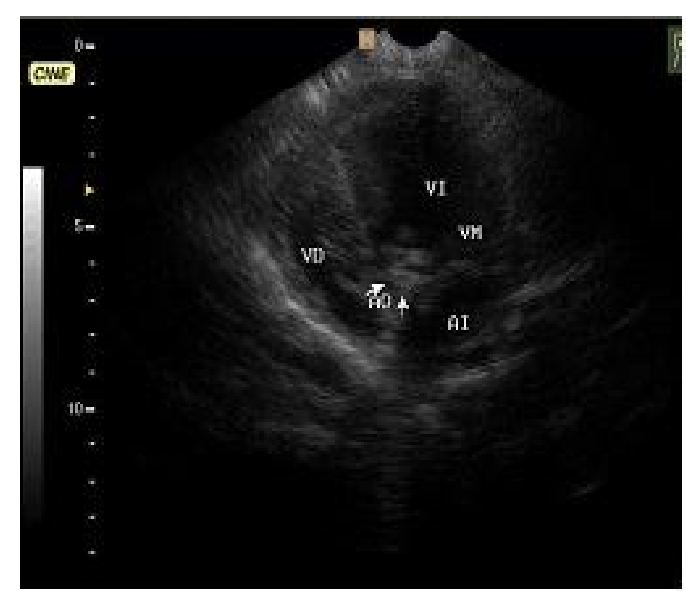

(a)

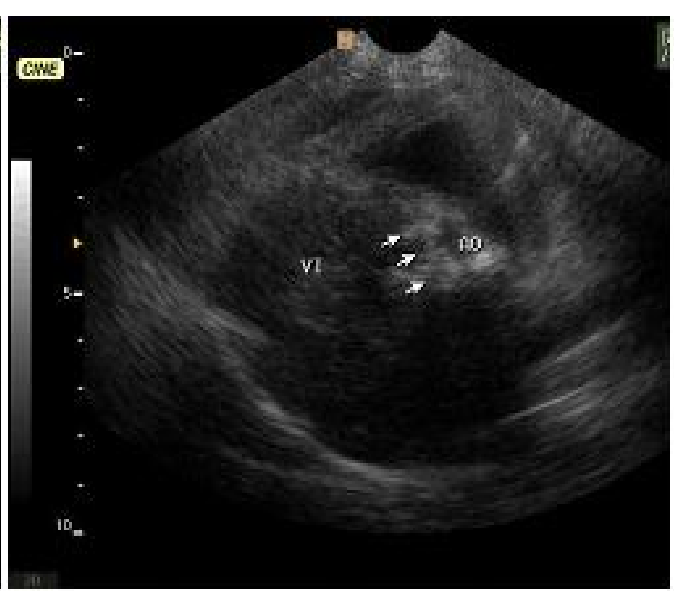

(b)

Figura 1. Ecocardiografía en modo B en una perra de 2.5 años de edad. (a) Vegetación a nivel aórtico, vista paraesternal izquierda (eje largo apical). (b) Vegetación a nivel aórtico, vista paraesternal derecha

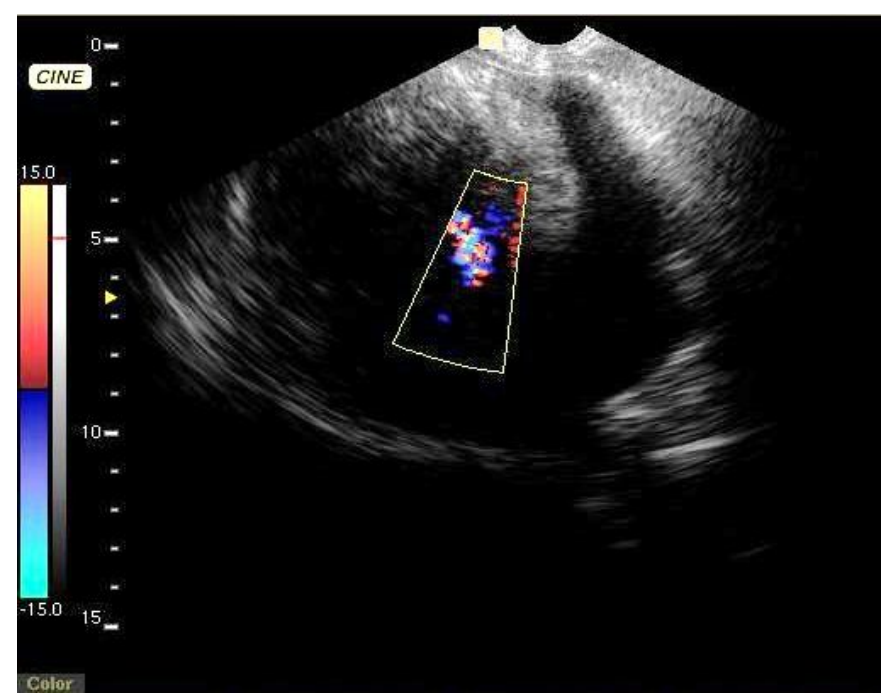

Figura 2. Ecocardiografía en modo doppler color en una perra de 2.5 años de edad. Presencia de reflujo diastólico en válvula aórtica

servó leucocitos y células renales en regular cantidad y bacterias en moderada cantidad. El descarte de leptospirosis dio negativo. En el examen radiográfico, la placa de tórax solo evidenció un aumento cardiaco ventricular izquierdo moderado. En los exámenes realizados en la otra clínica se encontró anemia normocítica normocrómica, leucocitosis con desviación a la izquierda, así como urea y creatinina elevadas.

El tratamiento inicial previo al descarte de leptospira consistió en bencilpenicilina ( 25 $000 \mathrm{UI} / \mathrm{kg} \mathrm{c} / 12 \mathrm{~h}$ ), además de tratamiento sintomático para la azotemia y la insuficiencia cardiaca congestiva. 
La ecocardiografía se pudo realizar cinco días después del ingreso del paciente debido a los limitados recursos económicos del dueño del animal. Los resultados ecocardiográficos mostraron un aumento del grosor del septo y de la pared libre ventricular izquierda, así como un aumento en el diámetro de la cámara ventricular izquierda en diástole. Asimismo, se evidenció una vegetación a nivel de la válvula aórtica (Fig. 1) y reflujo diastólico utilizando el doppler color (Fig. 2), dando la posibilidad de un diagnóstico de endocarditis bacteriana.

No se hizo un hemocultivo por decisión del dueño, por lo que se inició un tratamiento paliativo a base de antibiótico bactericida (amoxicilina + ácido clavulánico) a $20 \mathrm{mg} / \mathrm{kg}$ y enrofloxacino a $5 \mathrm{mg} / \mathrm{kg} \mathrm{c} / 12 \mathrm{~h}$. La paciente no presentó mejoría en los días subsiguientes y se recurrió a la eutanasia por decisión del dueño.

\section{Discusión}

Se dispone de diversos criterios para poder llegar al diagnóstico de una endocarditis bacteriana en el presente caso. Además de signos genéricos como la presencia de fiebre durante el examen clínico y de ser un paciente con más de $15 \mathrm{~kg}$ de peso; se pudo observar la falla renal, el hallazgo de vegetaciones en la ecocardiografía y la regurgitación aortica observada a través del doppler color. Lamentablemente, no se pudo realizar cultivos bacteriológicos ni se tuvo acceso a muestras histológicas para el diagnóstico definitivo; empero, se puede considerar este cuadro como una posible endocarditis bacteriana.

No obstante lo anterior, habría que considerar que los dos hemogramas reflejaron valores totalmente diferentes. El primero mostró una leucocitosis con desviación a la izquierda con una anemia normocítica normocrómica, mientras que el segundo mostró anemia macrocítica hipercrómica sin leucocitosis. Estos resultados podrían deber- se al uso de antibióticos bactericidas conconmitante con el uso de corticoides a dosis elevadas, secuestro a nivel valvular o una desviación a la izquierda degenerativa (Morales, 2007), dado que los valores difieren en más de 20000 leucocitos.

El ecocardiografía sigue siendo el método diagnóstico por imágenes con mayor sensibilidad para el diagnóstico de esta patología (Boon, 1998; Ettinger y Feldman, 2010), alcanzando valores de sensibilidad superiores al 90\% según Kittleson et al. (1998).

\section{Literatura Citada}

1. Belerian G, Mucha C, Camacho A. 2001. Afecciones cardiovasculares en pequeños animales. EEUU: Intermédica. $603 \mathrm{p}$.

2. Boon JA. 1998. Manual of veterinary echocardiography. Baltimore, USA: Williams y Wilkins. $478 \mathrm{p}$.

3. Ettinger SJ, Feldman EC. 2010. Textbook of veterinary internal medicine. Vol 2. $7^{\text {th }}$ ed. St. Louis, Missouri, USA: Saunders Elsevier. 1091 p.

4. Fox PR, Sisson D, Moüse NS. 1999. Textbook of canine and feline cardiology. Principles and clinical practice. $2^{\text {nd }}$ ed. Philadelphia: WB Saunders. 960 p.

5. Kittleson M, Kienle R. 1998. Small animal cardiovascular medicine. USA: Mosbi. 611 p.

6. Lynne N. 2003. Small animal cardiology. St. Louis, Missouri, USA: Elsiever Science. 208 p.

7. Martin M, Corcoran B. 1997. Cardiorespiratory diseases in the dog and cat. USA: Willey. $371 \mathrm{p}$.

8. Morales MJ. 2007. Atlas de hemocitología veterinaria. $2^{a}$ ed. Zaragoza, España: Servet. $184 \mathrm{p}$.

9. Tilley LP, Smith Jr FWK, Oyama MA, Sleeper MM. 2008. Manual of canine and feline cardiology. $4^{\text {th }}$ ed. St. Louis, Missouri, USA: Saunders Elsevier. 450 p. 